\title{
The general partnership under French law
}

\author{
by Frank Wooldridge
}

\section{INTRODUCTORY REMARKS}

The general partnership (société en nom collectif or SNC) is one of the commonest forms of business entity in France, and is employed especially by family companies. A good account of it appears in Ripert and Roblot, Traité de Droit Commercial, (10th edition, ed Germain, LGDJ, 2003, Book 1, pp 129 et seq), but it does not appear to have attracted much comment from English textwriters. Unlike the société en participation (SP), which is a purely private arrangement between the partners, and which resembles the Dutch and German silent partnerships, especially as it may be undisclosed, the SNC has legal personality which it acquires on entry into the Registry of Commerce and Companies. Like the much less common limited partnership or société en commandite simple (SCS), it has an ancient history. Roman counterparts and entities corresponding to general partnerships were used in medieval systems of law. The name société en nom collectif appears to derive from the writings of the distinguished French jurists Pothier and Savary. It has counterparts in most countries, but they are not always endowed with legal personality: this is the case with English and German partnerships.

The general partnership and the limited partnership are treated as personalistic entities by French jurists. Thus the share of a partner is, in principle at least, not transferable; the death or insolvency of a partner may lead to the dissolution of the partnership and partners in an SNC (general partnership) and commandités in an SCS are individually liable to the creditors for all the debts of the partnership. A partner in an SNC cannot require a creditor to join other partners before suing him for an outstanding partnership debt, eight days after an unsuccessful request for its payment has been made to the partnership by registered letter, or by a notice served by a court bailiff (mise en demeure).

A person who joins an existing general partnership is liable for debts and obligations incurred by the partnership before that date unless the partnership's articles exclude such liability. However, even though a person who ceases to be a partner continues to be liable for debts and obligations incurred before such retirement, such a person is not liable for debts and obligations incurred by the partnership after cessation, unless his name remains included in that of the partnership, or the cessation of his membership has not yet been entered in the Registry of
Commerce and Companies. It may be possible to escape certain of the onerous consequences of partnership liability by using private companies as members of partnerships (note in this sense G Ripert and R Roblot, Traité de Droit Commercial, 10th edition, ed Germain, LGDJ, 2003, Book 1, Vol 2, p 131). Such companies are only liable to the extent of their assets for the partnership's debts and obligations.

The dissolution of a general partnership has no effect on the extent of the obligations of its members. They remain jointly and severally liable towards third parties. However, the creditors lose their rights of action after four years have elapsed from publicity being given to the dissolution of the partnership.

Although an SNC, unlike an English partnership, is endowed with legal personality, it is transparent in certain respects. The transparency of a general partnership is thus shown by the fact that if such a partnership ceases to be able to make payments as they fall due, all the partners are treated as being in the same position. Since the enactment of the Law of 25 January 1985 (now see Commercial Code, art L221-16), when an order for judicial liquidation, or for the seizure of all his assets, or a measure prohibiting the exercise of a commercial activity, is made against a partner, the partnership is dissolved, unless its articles provide for its continuance in those circumstances, or the other partners unanimously decide in favour of such continuance.

\section{THE POSITION OF THE PARTNERS}

The members of a general partnership must all be merchants (commercants). They acquire such a capacity by becoming members of the partnership. As already indicated in principle 3, an SNC is dissolved if a member thereof becomes subject to an incapacity, or a prohibition from exercising a commercial activity (Commercial Code, art L221-16). A minor may not become a member of a general partnership even if he or she is emancipated. The partners act under the business name of the partnership, which may incorporate that of one or more of the partners, and must be preceded or followed immediately by the words société en nom collectif (Commercial Code, art L2212 ). The names of the partners appear in the extract from the partnership's articles which must be published. 
The partners may make contributions in cash, kind, or consist of services to be performed for the partnership (Civil Code, art 1843-3). The first two categories of contribution form the capital of the general partnership. If a cash contribution is to be made, interest is due thereon as from the time when it should have been provided. If the contribution is one of services to be performed, the prospective partner must give an account of all the earnings (gains) he has received from the performance of the services. An evaluation of any contributions in kind must appear in the partnership's articles, but there is no requirement for an independent evaluation of such contributions. Such contributions may sometimes consist of intellectual property rights.

The personalistic character of the general partnership is reflected in the fact that according to article L221-13 of the Commercial Code, the shares in an SSNC may not be represented by negotiable securities and may not be transferred to others without the consent of all the partners. Any clause in the articles having a contrary effect is treated as unwritten. Furthermore, article L221-15 of the Commercial Code provides that an SNC is dissolved by the death of one of the partners. These provisions would appear likely to cause considerable inconvenience. However, it is permissible to introduce a provision in the articles by which one of the partners reserves the right to transfer his share to a designated person. In addition, article L221-15 of the Companies Code allows the use of clauses in the articles permitting the continuation of the SNC in the event of the death of a partner, with all his heirs, or with a determined beneficiary, or a beneficiary to be determined.

The transfer of shares in the SNC takes place either through the medium of a notarial deed, or one under private signature (Commercial Code, art L221-14). In order to be opposable to the partnership, the transfer must take place in accordance with the requirements for the transfer of a credit provided for in article 1690 of the Civil Code, or by means of the deposit of an original copy of the act of transfer at the registered office of the partnership, accompanied by the delivery of a notification of the transfer. In order to be opposable to third parties, the transfer must be registered in the Registry of Commerce and Companies. This formality takes place by means of depositing the act of transfer in the annex to the Registry. It is also necessary to inform the registrar of the identity of the persons jointly and severally liable for the partnership debts.

Every partner in an SNC has the right to share in the profits: if no such right is granted to a partner the entity is treated as a nullity, on the grounds that it contains a leonine clause which is prohibited by the Civil Code. The partners are however entitled to share in the profits in any way that is desired. If there is no provision in the articles governing the division of the profits such division takes place in proportion to the capital contributions of the members. This rule may have an unfortunate impact upon a partner who makes a contribution consisting of services to be performed, because such a contribution is treated as being equal to that of the lowest capital contribution.

The apportionment of the losses takes place in accordance with the relevant provisions of the articles, and does not have to involve the same rules as does the apportionment of the profits. If a partner was exonerated from contributing to the losses by a provision in the articles, such a provision would be treated as being of a leonine character, and hence invalid by reason of article 1844-1(2) of the Civil Code.

\section{MANAGEMENT OF THE PARTNERSHIP}

\section{Appointment and dismissal of managers}

If the articles of the partnership contain no provision governing its management then each of the partners are treated as managers, and can separately take all the measures necessary for the management of the partnership (Commercial Code, art L221-3 and L221-4). Each such manager can validly sign documents on behalf of the partnership. It is more usual to limit the power of management to an individual person who does not necessarily have to be a partner. Such a manager may be appointed in the articles or by a procedure prescribed therein (art L221-3(1)). Such an appointment is also possible by an amendment of the articles. If the articles provide that they may be amended by a majority vote, a manager may be appointed by that majority. If the articles contain no provision governing the appointment of a manager, such an appointment may be made by a unanimous decision of the partners. The appointment of a manager has to be given publicity at the Registry of Commerce and Companies. If the period of appointment is not specified, it is treated as indefinite.

Managers may be commercial companies as well as individuals. According to article L221-3(2) of the Commercial Code, if an artificial person (personne morale) is appointed as a manager, its legal representatives (dirigéants) are subject to the same conditions and obligations and incur the same civil and criminal responsibilities as if they were individually managers of the partnership.

The rules governing the dismissal of managers are somewhat complex. Although there does not appear to be any clear legal text governing the matter, it appears that the court may remove a manager for good reason, at the request of one or more partners. Such reasons include dishonesty or incompetence (see Civil Code, article 1851(2), which applies to civil partnerships, and Commercial Code, article L223-25(2), which gives a power of dismissal in the case of managers of an SARL).

According to article L221-12 of the Commercial Code if all the partners are managers, or if one or more managers chosen by the partners are designated in the articles the dismissal of one of them may only take place by a 
unanimous decision of the other parties. Such dismissal entails the dissolution of the partnership, unless the articles otherwise provide, or the remaining partners unanimously agree to continue the partnership. The manager who is dismissed may withdraw from a partnership, and claim the reimbursement of the value of his shares therein.

Article L221-12 also provides that if one or more parties are managers, but are not so designated in the articles, they may be dismissed in accordance with the provisions of the articles, or in default of such provisions, by a unanimous resolution of the other partners. Such a dismissal does not result in the dissolution of the partnership. Finally, it also follows from article L221-12 that if the manager is not a partner, he may be dismissed in accordance with the provisions of the articles, or failing such provisions, by a simple majority decision of the partners.

It follows from the final sentence of article L221-12 that if a manager is dismissed without good reasons, he is entitled to damages. The former provision does not cover the resignation of a manger but it is established that if such a person resigns without good reasons (for example of health), the partnership may claim damages from him.

\section{Powers of the managers}

As far as relationships between partners are concerned, the power of the manager is principally determined by the content of the articles. These frequently indicate certain classes of acts which the manager can only perform with the assent of the partners. If no such assent is given, they incur personal responsibility. If there is no such clause in the articles, the manager possesses the power of performing all acts of management which are in the interest of the company. If there are several managers, each of them possesses the latter power, subject to the right of each manager to oppose the conclusion of the relevant transaction before it is entered into (Commercial Code article L221-4(1)).

According to article L221-5 of the Commercial Code, as far as relationships with third parties are concerned, the manager binds the partnership by transactions within the objects of the partnership. If there are several managers, each of them has the latter power of binding the partnership. The opposition of a manager to transactions engaged in by another has no effect on third parties, unless it can be shown that they were aware of it. Clauses in the articles which limit the powers of managers in accordance with the provisions of article L221-5(3) cannot be invoked as against third parties: these include a provision that the managers must act collectively. Such provisions are, however, binding as between the partners and the manager.

Thus, as far as third parties are concerned, the powers of the manager are limited by the objects of the partnership, which he cannot ignore or modify. Furthermore, restrictions arising from the powers granted to other organs of the partnership bind its manager, who cannot modify the rules contained in the partnership articles, for example by procuring its dissolution before the time fixed therein. A manager who does not act in the interests of the partnership may incur liability in damages thereto, where a harmful transaction within the objects of the partnership has been carried out. It would sometimes appear difficult to determine what are the objects of the partnership.

\section{Liabilities of the managers}

A manager is usually liable to the partnership if he causes it harm by a breach of the law or the articles, or by a fault of management. The partnership may act against such a manager through the medium of another manager or by means of the liquidators if the partnership is dissolved. In the event of inaction, it follows from article 1843-5 of the Civil Code that one or more partners could bring an action on behalf of the partnership against the managers in respect of the harm suffered by it, which may result in an award of damages. Any clause in the articles of the partnership which provides for the subordination of the action on behalf of the partnership to the giving of a preliminary opinion or authorisation by the meeting of the partners is treated as unwritten, as also is one which provides for renunciation of such an action in advance. In addition no resolution of the partners meeting can have the effect of the renunciation of an action against the managers in respect of their faults in management.

\section{Powers of the partners who are not managers}

The articles may confer power on the partners to do acts which fall within the administration of the partnership: such provisions are not binding on third parties, but they may prove useful in the operation of the partnership. The grant of this sovereign power of decision to the partners is understandable in view of the significant liabilities to which they may be subject. Furthermore, the partners are granted certain powers which may not be limited to excluded by the articles of the partnership. These include the appointment and dismissal of managers, the approval of the annual accounts, and the exercise of certain individual checks over the management and the accounts.

By article L221-6 of the Commercial Code, decisions which exceed the powers granted to the managers have to be taken unanimously by the partners. Nevertheless, the articles of the partnership may provide that certain decisions be taken by a majority stipulated in them. The articles may also provide that decisions be taken by means of a written consultation, unless one of the parties requests a meeting. The approval of the annual accounts would seem to require a meeting.

It appears to follow from many decided cases as well as from article 1836 of the Civil Code, that the alteration of the articles of a general partnership requires the approval of all the partners. The alteration must be published in a journal carrying legal notices, and also published in the Registry of Commerce and Companies. 


\section{Approval of the accounts}

At the end of each financial year, the manager prepares an inventory of the assets and liabilities existing at that time, and also the annual accounts, consisting of a balance sheet, profit and loss account and an annex, and where necessary consolidated accounts. He is also required to establish a report on the development of the partnership. These documents must be made available to the partners for their approval within six months of the closure of the financial year (Commercial Code, art L221-7). A meeting (as opposed to a written consultation) appears necessary for such approval. The report on the operations of the previous financial year, the annual accounts, texts of the proposed resolutions, the consolidated accounts (if any) and the report $\mathrm{n}$ the management of the group must be addressed by the partners within at least 15 days of the meeting.

\section{Individual controls over the accounts and the management}

According to article L221-8 of the Commercial Code, the partners who are not managers have the right, on two annual occasions, to obtain the books and documents of the partnership and to pose written questions on its management, to which the managers must reply in writing. In order to facilitate the exercise of their rights, such partners may make use of an expert whose name appears on one of the lists established by the appeal courts.

\section{Appointment of an auditor}

This has been required in SNCs since May 1, 1984, when two out of the three following requirements have been satisfied. These are a balance sheet total of at least $€ 1,550,000$, a turnover less tax of at least $€ 3,100,000$, and an average number of employees of 50 or more. It follows from article L221-9 of the Commercial Code that even if these limits have not been attained, the partner may request the court to make such an appointment. According to article L822-11 of the Commercial Code, which contains a general principle applicable to all companies and general partnerships, the auditor may not directly or indirectly take, receive or retain an interest in the legal person whose accounts he is entrusted with auditing, or in another legal person which controls or is controlled by the former legal person.

\section{EFFECT OF A PARTNER'S DEATH}

The personalistic character of an SNC means that the death of a partner in principle results in the dissolution of the partnership. Such dissolution may also result from the bankruptcy of a partner, or if he/she ceases to be qualified to engage in a commercial activity, unless the articles of the partnership provided for its continuation in these circumstances, or the remaining partners unanimously decide to carry on the business (Commercial Code, art L221-16). Article L221-15 of the Commercial Code contains provisions which may be included in the articles of a partnership enabling it to continue on the death of a partner.

Thus, article L221-15(2) provides that if it is stipulated that on the death of one of the partners, the partnership continues with his heirs, or only with the surviving partners, these provisions have effect, with the reservation that, in order to become a partner, the heir must be accepted by the other partners. Such acceptance must be unanimous. Article L221-15(3) provides that the position is the same if it is stipulated that the partnership continues, either with the surviving spouse or with one or more of the heirs, or with any other person designated in the articles, or if the articles so provide by testamentary disposition. Such a clause may well be coupled with the provision that the relevant person must be accepted by the partners.

By article L221-15(5), when the partnership continues in accordance with the provisions of article L221-15(3), those who benefit from the stipulation are liable to account to the estate of the deceased partner for the value of the shares which they have received. However, this may not always be required in practice.

\section{CONCLUDING REMARKS}

Despite the potentially onerous liabilities of the partner, the general partnership remains in common use in France. In certain professions it is replaced by the civil partnership, which appears to have been the subject of a considerable amount of legislation and to have increased in importance in recent years. The general partnership (SNC) is a vehicle much employed by family businesses. The alternative of the SARL (société à responsabilité limitée) is available to them, but the creditors of such a private company often demand personal guarantees from their managers (gérants). Both the SNC and SARL and indeed the civil partnership are required to conform with formalities after their articles have been signed regarding such matters as notices in a newspaper carrying legal announcements, and entry in the Registry of Commerce and Companies.

\section{Dr Frank Wooldridge}

Professional Fellow, British Institute of International and Comparative Law 